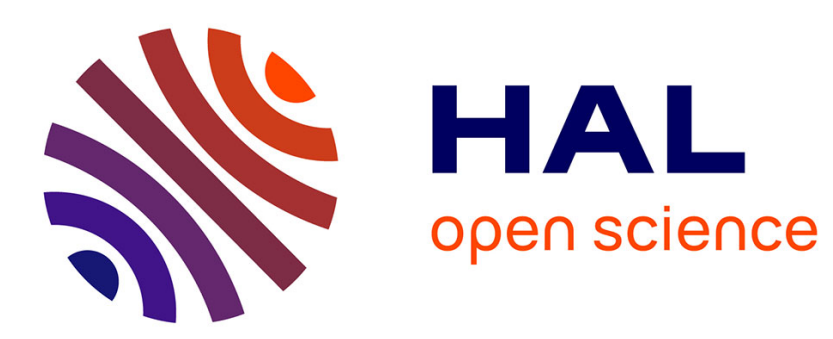

\title{
Two-photon excitation of the [MATH] transitions of Ce3+ in LuPO4: a comparison between theoretical and experimental intensities
}

J. Sztucki, J. Sytsma

\section{- To cite this version:}

J. Sztucki, J. Sytsma. Two-photon excitation of the [MATH] transitions of Ce3+ in LuPO4: a comparison between theoretical and experimental intensities. Journal de Physique IV Proceedings, 1994, 04 (C4), pp.C4-611-C4-611. 10.1051/jp4:19944161 . jpa-00252618

\section{HAL Id: jpa-00252618 https://hal.science/jpa-00252618}

Submitted on 1 Jan 1994

HAL is a multi-disciplinary open access archive for the deposit and dissemination of scientific research documents, whether they are published or not. The documents may come from teaching and research institutions in France or abroad, or from public or private research centers.
L'archive ouverte pluridisciplinaire HAL, est destinée au dépôt et à la diffusion de documents scientifiques de niveau recherche, publiés ou non, émanant des établissements d'enseignement et de recherche français ou étrangers, des laboratoires publics ou privés. 


\title{
Two-photon excitation of the $4 f^{1} \rightarrow 5 d^{1}$ transitions of $\mathrm{Ce}^{3+}$ in $\mathrm{LuPO}_{4}$ : a comparison between theoretical and experimental intensities
}

\section{J. SZTUCKI ${ }^{*},(1)$ and J. SYTSMA ${ }^{* *}$}

* Institut de Physique Nucléaire de Lyon, IN2P3-CNRS et Université Claude Bernard, 43 Bd du 11 Novembre 1918, 69622 Villeurbanne cedex, France

** Chemical Sciences Division, Lawrence Berkeley Laboratory, Berkeley CA 94720, U.S.A.

\begin{abstract}
The theory of two-photon $\mathrm{f}-\mathrm{d}$ transitions developed by Sztucki and Stręk has been adopted to the particular case of the $\mathrm{Ce}^{3+}$ ion in $\mathrm{LuPO}_{4}$. The intensities of twophoton transitions from the ground state $4 f^{1}\left(\Gamma_{6}\right)$ to the five crystal-field components of the $5 d^{1}$ state has been calculated and compared with the experimental data. It has been shown that the crystal-field mechanism is not able to reproduce the experimental results properly. Taking into account the contribution produced by light induced polarization of ligands (so called dynamic mechanism) led to the fairly good agreement between theory and experiment.

It has been demonstrated how the analysis of the relative intensities of TP transitions can serve as an experimental test of the theoretical ratio between the static and dynamic contributions.
\end{abstract}

(1) Permanent address: Instytut Niskich Temperatur i Badań Strukturalnych, P.A.N., skr. poczt. 937, 50-950 Wrockaw, Poland 